\title{
Peace Education as a Post-conflict Peacebuilding Tool ${ }^{1}$
}

\author{
Vanessa Tinker \\ Hacettepe University
}

\begin{abstract}
This article provides a critical analysis of the literature and reports on peace education programmes in countries emerging from violent conflicts. First, it begins with an overview of peace education's history. Next, it examines how peace education has been conceptualised, and highlights why it remains poorly defined. The article then proceeds by looking at the development of the international community's use of peace education as a tool to contribute to their peacebuilding efforts in countries emerging from protracted contexts. After that, it reviews the research and evaluation work that has been done on peace education programmes. The article concludes with a survey of peace education programmes in ethnically/religiously linked post-conflict environments that have made mainstreaming their goal, and identifies areas of future research.
\end{abstract}

Keywords: Peace, peace education, peacebuilding, post-conflict reconstruction, protracted conflicts

\section{Introduction}

The practice of peace education is as old as war itself. For generations, people have sought to find ways to prevent war and violence and educate on ways to be peaceful. Some of the oldest theories of peace education derive from the worlds' religions, following the teaching of such prophets as Buddha, Ballá'u' 'láh, Jesus Christ, Mohammed, Moses, and Lao Tse. ${ }^{2}$ This article maintains that many peace education programmes today, even those that present themselves in purely secular terms, continue to draw inspiration and insight from this religious heritage, directly and indirectly influencing the programmes' philosophical assumptions underpinning their theories and practices.

However, it was only after the end of the Second World War that peace education became consciously practiced in formal and informal educational settings, evolving and developing into the distinct field of research and practice that it is today. This article provides a critical analysis of the literature and reports on peace education programmes in countries emerging from violent conflicts. It begins with an overview of peace education's history. Then it examines how peace education has been conceptualised, and highlights why it remains

Vanessa Tinker, Lecturer, Department of International Relations, Hacettepe University, Ankara, Turkey. Email: vanessatinker@ hotmail.com.

1 This article represents a modified version of a chapter taken from: Vanessa Tinker, Education for Peace: The Politics of Adopting and Mainstreaming Peace Education Programs in Post-Conflict Settings (San Francisco: Academica Press, 2015).

2 Ian Harris, "The Conceptual Underpinnings of Peace Education," in Peace Education: The concept, principles and practices in the world, ed. Gabriel Salomon and Baruch Neve (Mahwah, NJ: Lawrence Erlbaum, 2002), 15-26. 
poorly defined. The article then proceeds by looking at the development of the international community's use of peace education as a tool to contribute to their peacebuilding efforts in countries emerging from protracted contexts. It next reviews the research and evaluation work that has been done on peace education programmes. The article concludes with a survey of peace education programmes in ethnically/religiously linked post-conflict environments that have made mainstreaming their goal, and identifies areas of future research.

\section{The Emergence of the Field of Peace Education}

Following the First World War, education reformers and peace advocates from Europe and America, such as Maria Montessori and John Dewey, began promoting the idea of "education for international understanding." It was assumed that ignorance of different cultures and political systems had historically led to distrust, suspicion, and often to war. Therefore it was hypothesized that through education it was possible to prevent future wars by changing former attitudes and behaviours to those more conducive to the creation of peace. Schools likewise began incorporating international relations into their curricula.

The idea to provide education for international understanding gained further attention and support after the Second World War, when the international community, through the newly established United Nations (UN), acknowledged traditional diplomacy as inadequate to respond to international conflicts. Many world leaders within the UN, and through its interagency, UNESCO (the United Nations Educational, Scientific and Cultural Organization), proposed developing some kind of intellectual and moral framework that would unite the hearts and minds of humankind towards the goal of achieving lasting peace. Education was likewise turned to as the primary tool to achieve this objective.

Education had been used during both world wars as a tool to promote extreme nationalism through the indoctrination of youth in formal schooling. To counteract this trend, UNESCO promoted the idea of "education for world citizenship." UNESCO asserted that "wars begin in the minds of men" and therefore "it was in the minds of men that the defences of peace must be constructed" (UNESCO, 1945). Since then, UNESCO has sought through education to advance international peace and the common welfare of humankind by developing international documents and proposals on ways to improve curricula and teacher training.

Peace education's formative years began as a study on the causes of war and other forms of direct violence and strategies to reduce or eliminate them. However, in the 1960s and 1970s, peace educators such as Johan Galtung elaborated and expanded on this conceptualization to include structural and cultural violence. Peace educators from around the world have since then adopted and adapted peace education programmes to address violence according to their specific social and political contexts. To illustrate a few examples, Japan introduced "a-bomb education" in the 1950s to counter fears following the aftermath of the atomic bombs in Hiroshima and Nagasaki. ${ }^{3}$ South America in the 1960s began initiating "development education" in response to the increase of violence caused by power and underdevelopment. ${ }^{4}$ In the late 1980s, Ireland initiated a peace education programme called "education for mutual understanding" to reintegrate divided Catholic and Protestant communities. ${ }^{5}$ Also in the

3 Harris, "The Conceptual Underpinnings of Peace Education," 16.

4 Harris, "The Conceptual Underpinnings of Peace Education," 16

Terrence Duffy, "Peace Education in a Divided Society: Creating a Culture of Peace in Northern Ireland," Prospects XXX, no. 1 (2000): 15-29. 
1980s, the United States and Great Britain offered "nuclear education" to prevent a "nuclear holocaust" from occurring. ${ }^{6}$ Peace education programmes have since then gone by a number of other names, including anti-nuclearism, international understanding, citizenship, global education, environmental responsibility, communication skills, conflict resolution, critical pedagogy, life skills, democracy, coexistence and gender equality, human rights awareness, peacebuilding, and tolerance of diversity. ${ }^{7}$ Each approach offers a different perception on how peace can be 'mainstreamed' in basic education. ${ }^{8}$

One of the newest developments in the field of peace education is its use by international actors as a peacebuilding tool in countries emerging from violent conflicts following the end of the Cold War. It is hoped that through peace education, succeeding generations will learn how to deal with conflicts non-violently and to eventually sustain a culture of peace. ${ }^{9}$ The remainder of this article will focus only on peace education programmes in this post-Cold War context, a phenomenon that remains poorly defined and understudied.

\section{The Conceptual Framework of Peace Education}

The concept of peace education has been used to refer to a wide range of approaches and diverse social contexts. It represents a variety of different but inter-related peace-based educational activities. UNICEF defines peace education as "the process of promoting the knowledge, skills, attitudes and values needed to bring about behaviour changes that will enable children, youth and adults to prevent conflict and violence, both overt and structural; to resolve conflict peacefully; and to create the conditions conducive to peace, whether at an intrapersonal, interpersonal, intergroup, national or international level." ${ }^{10}$ This definition is intended to be both specific and general, to address the many social and political contexts around the world. ${ }^{11}$ The definition is thought to represent a combination of practical experiences gained by peace education practitioners in developing as well as industrialized countries, in addition to ideas that have emerged from scholarly work and research in peace and conflict studies. ${ }^{12}$

However, efforts to pool such a diverse range of programmes and place them under one single label has been criticized, questioned, and found self-defeating by a number of peace educators in the field, especially those working in the context of protracted conflicts. By defining and interpreting the field of peace education so broadly, Salomon argues that it "glosses over profoundly different kinds of peace education" and "implicitly assumes that

\footnotetext{
Harris, "The Conceptual Underpinnings of Peace Education," 17

Lisa Ardizzone, "Towards Global Understanding: The Transformative Role of Peace Education," Current Issues in Comparative Education 4, no. 2 (2002): 16-25; Daniel Bar-Tal, "The Elusive Nature of Peace Education," in Salomon and Neve, Peace Education, 27-36; Kenneth Bush and Diana Saltarelli, The Two Faces of Education in Ethnic Conflict (New York: UNICEF, 2000); Sara Clarke-Habibi, "Transforming Worldviews: The Case of Education for Peace in Bosnia and Herzegovina," Journal of Transformative Education 3, no. 1 (2005): 33-56; H. B. Danesh, "Towards an Integrative Theory of Peace Education," Journal of Peace Education 3, no. 1 (2006): 55-78; Maria Fitzduff and Isabella Jean, Peace Education: State of the Field and Lessons Learned From USIP Grantmaking (Washington, DC: United States Institute for Peace, 2011).

8 Susan Fountain, "Peace Education in UNICEF" (working paper, Programme Division, Education Section, UNICEF, New York, 1999).

9 UN states that, "The culture of peace is based on the principles established in the Charter of the United Nations and on the respect for human rights, democracy and tolerance, the promotion of development, education for peace, the free flow of information and the wider participation of women as an integral approach to preventing violence and conflicts, and efforts aimed at the creation of conditions for peace and its consolidation (A/Res/52/13, 15 January 1998, para.2).

10 Fountain, "Peace Education in UNICEF," 1.

11 Gabriel Salomon, "Peace Education: Its Nature, Nurture, and the Challenges it Faces," in Handbook on Building Cultures of Peace, ed. Joseph de Rivera (New York: Springer Science+Business Media, LLC, 2009), 107-21.

12 Fountain, "Peace Education in UNICEF."
} 
education for human dignity and human rights, democracy, and nonviolence translates into situational-specific, context-appropriate behaviors and actions." ${ }^{13}$ Porath adds "that authors disagree on the description of the problem they wish to address and correspondingly on the proper solution, as well as on the site in which peace education is to take place." ${ }^{14}$ According to scholars in the field, this semantic broadness has inhibited the field's scholarly advance in terms of theorizing, research, and programme evaluation.

To address some of these shortcomings and academically develop the field of peace education, Salomon suggests analysing and distinguishing programmes according to the socio-political context they take place in, of which he identifies three: 1) regions that are in or emerging from [protracted] ${ }^{15}$ conflicts (e.g. Northern Ireland, Kosovo, Israel, Cyprus, and Bosnia and Herzegovina (BiH)), 2) areas where there exist nonviolent inter-ethnic tensions based on ethnocentrism (e.g. immigrants in Belgium and African-American, Hispanic, and Indigenous people in the US), and 3) relatively peaceful areas (e.g. Sweden, Norway, and Switzerland). These distinctions derive from the challenges programmes face, their goals, and the approach regarding different sub-groups of participants. ${ }^{16}$

\section{Peace Education in the Context of Protracted Conflicts}

Nevertheless, as research has demonstrated, peace education programmes in the context of protracted conflicts continue to represent a range of practices (e.g. conflict resolution, multiculturalism, with cross-cultural training, and the encouragement of a peaceful disposition); a number of different challenges (e.g. conflicting collective narratives, mutually exclusive historical memories, deeply rooted beliefs about the conflict and the adversary, grave inequalities, and a belligerent social climate); pursue a variety of goals (e.g. the cultivation of understanding between adversaries, the development of mutual tolerance, empathy and positive disposition towards other groups and a peaceful outlook in general; seek societal changes at different levels - intrapersonal, interpersonal, intergroup, and international and encompass a wide range of activities (e.g. curriculum development and reform, retraining of teachers, address structural and policy changes required to mainstream peace education, promoting initiatives at the community level, and engaging in public awareness campaigns). These programmes reflect a wide range of conceptual frameworks originating from different religions or ideologies, which in turn envision different routes to peace. Therefore, peace education remains an elusive concept because there is no agreed-upon definition of peace or the means to achieve it. Consequently, Bar-Tal argues each programme projects its "own particular vision of a desirable society, the means to achieve it, and the school's role in this mission," and he concludes that "the consequence is the very multifaceted state of peace education we see at the present time."17

\footnotetext{
${ }^{13}$ Salomon, "Peace Education," 107.

${ }^{14}$ Sigal Ben-Porath, "War and Peace Education," Journal of Philosophy of Education 37, no. 3 (2003): 525.

15 Within the field of peace and conflict studies and peace education, practitioners have used the term "intractable" conflicts instead of "protracted" conflicts; some use other terms such as deep-rooted, ethnic, or identity-based conflicts. Given the absence of an agreed-upon term to describe contemporary conflicts, this article uses the term "protracted conflict."

${ }^{16}$ Gabriel Salomon, "The Nature of Peace Education: Not All Programs Are Created Equal," in Salomon and Neve, Peace Education, 5 .

17 Bar-Tal, "The Elusive Nature of Peace Education,” 27-8.
} 


\subsection{Defining violence and peace in peace education}

As formally discussed in this article, Johan Galtung, considered to be the father of peace studies, has sought to distinguish between different types of violence to include direct (e.g. verbal, physical, and violence harming the body, mind, or spirit), structural (e.g. political, repressive, economic, exploitative; supported by structural penetration, segmentation, fragmentation and marginalization), and cultural violence (e.g. religion, law, ideology, language, art, empirical/formal science, cosmology, and by carriers such as schools, universities, and media). ${ }^{18}$ Likewise, he has elaborated on the concept of peace, making the distinction between negative peace (e.g. the absence of war, gang attacks, sexual assault, random killing, and all other forms of physical harm) and positive peace (e.g. the existence of social and cultural structures that contribute to the well-being of all citizens. ${ }^{19}$

For many peace scholars however, the definition of peace does not go far enough. Peace educators such as Clarke-Habibi ${ }^{20}$ argue that the moral and spiritual dimensions of peace need to be included, as some of the greatest peace-builders of the last century did (e.g. Martin Luther King Jr., Mahatma Ghandi, Maria Montessori). Peace scholar Gur-Ze'ev has gone further by suggesting that concept of peace itself derives from a theological origin, even in its secular form. ${ }^{21}$

While most peace educators and practitioners today agree that peace is more than the absence of direct violence (negative peace), the deeper meaning of peace (positive peace) remains undetermined. Peace educators such as Betty Reardon ${ }^{22}$ maintain that a holistic approach to peace education is needed, one that leads to inclusive education practices that incorporate global, social, political, moral, and personal dimensions of peace. Such an approach also complements and assists UN efforts to promote a "culture of peace."

Peace educators working from negative interpretations of peace, however, criticize attempts to elaborate on the meaning of peace, suggesting that doing so is responsible for much of the conceptual confusion and incoherence within the field. Critics also maintain that peace education programmes working from positive conceptualizations have become too ambitious, with their goals of eliminating and/or reducing all forms of indirect violence, thereby running the risk of disillusioning participants or worse, imposing, even if unconsciously, indirect forms of cultural violence. ${ }^{23}$ Finally, critics argue that idealist and/or positive peace-based approaches have been less effective partly because they have failed to make explicit the type of social change and/or ends sought in the immediate, local, national, and international contexts. ${ }^{24}$

Following this brief literature review, it is apparent that two dominant philosophical and theoretical approaches to peace education exist -idealist and functionalist. This article argues that both approaches represent regimes of truth, each deriving from diverse religions and/ or ideologies. Although they disagree on the conceptualizations of peace and violence, both regimes aspire for peace through the use of peace education. This understanding illustrates

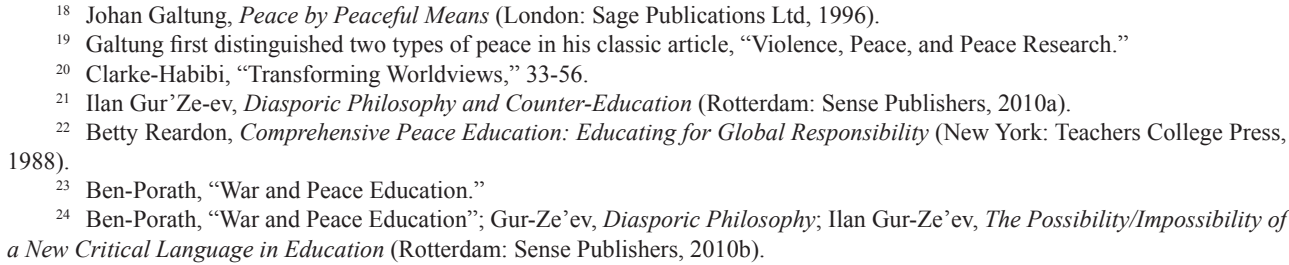


that the quest for peace is not politically or culturally "neutral," a fact that has only recently been reflected on or problematized. Peace education programmes continue to be developed in countries emerging from protracted conflict with practically no reflection on the foundation of their assumptions; rather, their rationality is assumed and never questioned. This thinking represents a potential 'blind spot' in the field of peace education. This article next examines how this phenomenon came to exist.

\section{The Emergence of Peace Education as a Post-War Policy Tool of Peacebuilding}

After the Cold War, a series of intra-state conflicts broke out in Central America, Southeast Europe, Sub-Saharan Africa, and Southeast Asia. These conflicts have been referred to as protracted social conflicts, a concept developed by Azar ${ }^{25}$ to distinguish them from inter-state conflicts. Protracted conflicts are marked by tremendous human loss and suffering, economic devastation, a breakdown of governance and/or political systems, and cause development setbacks. They impact every aspect of society and include "a mixture of ideological, political or resource issues with elements of communal and ethnic [racial, national, or religious] identity." ${ }^{26}$ Unlike inter-state wars, civilians, in particular women and children, are often targeted due to their membership within a particular community. Strategies often include sexual torture, mass rape, ethnic or social "cleansing," and even genocide. Protracted conflicts may last for several generations due to their high levels of intensity and the duration of violence.

In response to these new disasters, the UN developed and proposed a number of strategies, outlined in An Agenda for Peace, including "preventative diplomacy," "peacemaking," "peacekeeping, and "peacebuilding." 27 This paper focuses on peacebuilding, as it deals specifically with countries emerging from intra-state conflicts. The strategy of peacebuilding is defined by the UN and other private voluntary organizations as the aim to "identify and support structures which will tend to consolidate peace and advance a sense of confidence and well-being among people" in addition to "address[ing] the deepest causes of conflict." 28 Since the end of the Cold War, UN peacebuilding operations have become increasingly ambitious and more complex. Initially, peacebuilding operations focused on rebuilding institutions and providing basic services (e.g. security, rule of law). However, in recent years, Paris argues that peacebuilding operations have sought "to 'transplant' the values and institutions of the liberal democratic core into the domestic affairs of peripheral host states." ${ }^{29}$ This change is in part because it is assumed that democratic institutions and market mechanisms will provide the stable foundations for peace both internally and externally. ${ }^{30}$

\footnotetext{
25 Edward Azar, The Management of Protracted Social Conflict (Aldershot: Dartmouth, 1990).

26 Veronique Dudouet, "Transitions for Violence to Peace," in Berghof Handbook for Conflict Transformation (Berlin: Berghof Research Center for Constructive Conflict Management, 2006), 3.

27 It should be noted that there exists no strong consensus on the definition of peacebuilding or the best means to achieve it. The term peacebuilding was originally coined in 1975 by one of the founders of Peace Studies, Johan Galtung, in his article, "Three Approaches to Peace: Peacekeeping, Peacemaking, and Peacebuilding." His observations have now come to define today's notion of peacebuilding, namely the idea of addressing the "root causes" of violent conflict and of supporting local capacity to peacefully manage and resolve conflicts. In 1997, another key scholar in Peace Studies, Paul Lederach, called for the broadening of our understanding of peacebuilding to include more than simply resolving conflicts. He proposed transforming conflicts into something more sustainable and conducive to rebuilding relationships. Both approaches of peacebuilding suggest more of a bottomup approach, unlike the UN's method, which tends to be more top-down.

28 Boutros Boutros-Ghali, An Agenda for Peace (New York: United Nations, 1992), 15. 638.

29 Roland Paris, "International Peacebuilding and 'Mission Civilistrace'," Review of International Studies 28, no. 4 (2002): 
In earlier peacebuilding operations, particularly in 1989 to 2005, education was not made a high priority by the international community. Only 11 out of 37 peace agreements for example mentioned education. ${ }^{31}$ Those that did focused on post-war priorities, referred to as "education in emergencies," which included the physical repair and assurance of safe access to schools. ${ }^{32}$ This was in part because the international community recognized education as a domestic issue that would require a long-time commitment, as US occupation in post-World War II Germany and Japan demonstrated. ${ }^{33}$

By the late 1990s, the international community began to shift its priorities and include education as part of its peacebuilding strategy. This change was in part due to the mounting evidence from researchers and practitioners that the content, structure, and delivery of education might be undermining organizations' peacebuilding efforts by reinforcing the social divisions that were the deepest cause of the conflict in the first place. ${ }^{34}$ In the cases of Lebanon, Northern Ireland, Mozambique, and Bosnia and Herzegovina, for example, education was used as a weapon in cultural repression, to manipulate history for political purposes, and to reinforce segregation, inequality, and stereotyping. ${ }^{35}$

Recognising the negative ways education can be used, the international community has also come to recognise the positive and strategic role it can play in post-conflict countries. Now, peace education programmes are included in the many education-related projects and initiatives the international community has supported. The international community has assumed that by mainstreaming peace education programmes in formal educational systems, it will assist them in their peacebuilding efforts by dampening the impact of conflicts. Education is now recognized as a major contributor to peace processes by nurturing an ethnically tolerant climate, desegregating minds, improving linguistic tolerance, cultivating a sense of inclusive citizenship, aiding in the disarmament of history, and contributing to national reconciliation and peacebuilding. ${ }^{36}$ Peace education programmes, like peacebuilding missions more generally, are also seen as a means of disseminating "Western" core values and beliefs in - among other things - democratic governance, free market economics, and human rights, embedding these tenets into curriculums, teacher instruction, and education institutions' frameworks. ${ }^{37}$ Finally, peace education programmes are considered critical in

liberal democracies are more peaceful. See Michael Doyle, "Liberalism and World Politics," The American Political Science Review 80, no. 4 (1986): 1151-169.

31 Save the Children Norway, "Building Peace Out of War: Children and Young People as Agents of Peace- The Young Generations Challenge" (paper presented at the International Conference, Oslo Norway, June 29-July 3, 2005).

32 Mary Pigozzi, Education in Emergencies and for Reconstruction: A Developmental Approach (New York: United Nations Children's Fund, 1999); Marc Sommers, "Peace Education and Refugee Youth," in Learning for a Future: Refugee Education in Developing Countries, ed. Jeff Crisp, Christopher Talbot and Daiana B. Cipollone (Geneva: UNHCR, 2002), $163-216$.

33 James Tent, Mission on the Rhine: Reeducation and Denazification in American-Occupied Germany (Chicago: University of Chicago, 1982).

${ }^{34}$ Kenneth D. Bush and Diana Saltarelli, The Two Faces of Education in Ethnic Conflict (New York: UNICEF, 2000); Valerie Perry, "Reading, Writing, and Reconciliation: Educational Reform in Bosnia and Herzegovina," (working paper no. 18, European Centre for Minority Issues, Flensburg 2003); Sobhi Tawil and Alexandra Harley, Education, Conflict and Social Cohesion (Geneva: UNESCO International Bureau of Education, 2004); Alan Smith, "The Influence of Education on Conflict and Peace Building" (background paper prepared for the Education for All Global Monitoring Report 2011: The Hidden Crisis - Armed Conflict and Education, UNSECO, Paris, 2010); Kathryn Tomlinson and Pauline Benefield, Education and Conflict: Research and Research Possibilities (Berkshire,UK: National Foundation for Educational Research, 2005).

35 Tawil and Harley, Education, Conflict and Social Cohesion, 5.

${ }^{36}$ Bush and Saltarelli, The Two Faces of Education; Fountain, "Peace Education in UNICEF"; World Bank, Reshaping the Future: Education and Post-Conflict Reconstruction (Washington DC: World Bank, 2005); Smith, "The Influence of Education on Conflict and Peace Building."

37 Ardizzone, "Towards Global Understanding: The Transformative Role of Peace Education"; Sommers, "Peace education and refugee youth"; Klaus Seitz, Education and Conflict: The Role of Education in the Creation, Prevention, and resolution of societal crises - Consequences for Development Cooperation (Postfach: German Technical Cooperation, 2004). 
terms of linking top-down and bottom-up approaches to peace- and state-building. ${ }^{38}$ These assumptions, however, as this next section will demonstrate, are based on limited empirical evidence and research.

\subsection{Evaluation of peace education programmes}

Without an agreed-upon conceptual framework, the literature has highlighted how the task of evaluating peace education programmes has remained difficult. ${ }^{39}$ Furthermore, a study by Neve and Brem $^{40}$ found that only a few evaluations have been carried out on peace education programmes in the context of protracted conflicts. The lack of a clear conceptual framework and empirical evaluative evidence has led many within the field to criticize and even question the use of peace education as a post-conflict peacebuilding tool. ${ }^{41}$

Assessments have mainly consisted of project descriptions and opinion pieces based on subjective and self-reinforcing criteria. Generally these have ignored or failed to question the cultural assumptions underlying the programmes and how they may affect the societies in which they are implemented. Neve and Brem suggest low levels of awareness concerning the importance and usefulness of evaluation, the lack of expertise in evaluation methodology, budgetary and time constraints, and general avoidance as the leading reasons the evaluation of peace education programs remains underdeveloped. ${ }^{42}$ Steinburg has gone further by criticizing the field for its lack of "empirically useful analyses and prescriptions for resolving or managing protracted ethno-national conflicts," although partially excusing this shortcoming due to the complexity of the subject. ${ }^{43}$

Although existing evaluations suggest encouraging results, they are based on an insufficient number of case studies. Reports have consisted of formative or summative assessments, either focusing on programme improvement or the impact of peace education instruction on participants, respectively. ${ }^{44}$ Further, the overall purpose and meaning of peace education has been taken for granted in all of them. To date, only a number of descriptive and normative case studies have been conducted on peace education programmes in the context of protracted conflicts (e.g. Bosnia-Herzegovina, the Middle East, Cyprus, Northern Ireland, Israel-Palestine, and South Africa, to name just a few). Often these studies have been tautological, without any independent and externally measurable variables to determine a programme's success and/or failure, all of which has failed to provide academic scholarship with any enriching empirical data. ${ }^{45}$ In the case of UNICEF, Fountain notes that "there is a clear need for systematic research and [the] evaluation of peace education programmes in UNICEF, in order to provide more information on factors that contribute to effectiveness in the wide range of social and cultural contexts in which UNICEF operates. Relatively

${ }_{38}$ Fitzduff and Jean, Peace Education; Valerie Perry and Soeren Keil, "The OSCE Mission in Bosnia and Herzegovina: Testing the Limits of Ownership," Nationalities Papers: The Journal of Nationalism and Ethnicity 41, no. 3 (2013): 71-394.

39 Sommers, "Peace Education and Refugee Youth"; Ian Harris, "Peace Education Evaluation" (paper presented at the annual meeting of the American Educational Research Association, 21-25 April, Chicago, IL, 2003); Salomon, "The Nature of Peace Education"; Salomon, "Peace Education"; Fitzduff and Jean, Peace Education.

${ }^{40}$ Baruch Neve and Iris Brem, "Peace Education Programs and the Evaluation of their Effectiveness," in Salomon and Neve, Peace Education, 271-82.

${ }^{41}$ Ilan Gur'Ze-ev, "Philosophy of Peace Education in a Post-Modern Era," Education Theory 51, no. 3 (2001): 315-36; Gur'Zeev, Diasporic Philosophy; Gur'Ze-ev, The Possibility/Impossibility.

42 Neve and Brem, "Peace Education Programs and the Evaluation of their Effectiveness," 275.

43 Gerald Steinburg, "The Thin Line Between Peace Education and Political Advocacy: Toward a Code of Conduct," in Educating Towards a Culture of Peace, ed. Yaacov Iram (Greenwhich, CT: Information Age, 2004), 15.

44 Harris, "Peace Education Evaluation."

45 Steinburg, "The Thin Line between Peace Education and Political Advocacy: Toward a Code of Conduct." 
few systematic attempts to evaluate peace education programmes have been carried out by UNICEF offices so far." 46

The lack of empirical research and evaluation represents a second shortcoming of the field. As this article has highlighted, those working within the field are aware of the importance of empirical research in terms of documenting best practices, recording lessons learned, improving the quality of programs, demonstrating to funders that they are getting 'value for their money,' and in understanding how they are contributing to the reduction of violence and the construction of a culture of peace. ${ }^{47}$ Harris adds that those working within the field face intense pressure to prove to the educational research community, policy makers, taxpayers, and the peace community that their peace education programmes are reducing violence. ${ }^{48}$ Perhaps more importantly, this article draws attention to how the lack of evaluation reflects an absence of accountability in terms of determining what impact these programs are having on participants, and whether they are yielding their intended results. These shortcomings, however, have been excused by comparing the situation to the field of medicine 200 years ago, where "much activity [was] based on lots of good intentions, unchecked assumptions, and partly naïve beliefs with little scholarship to either guide or accompany it." 49 Research on peace education, like earlier applications of science to medicine, has also been primarily carried out on the basis of rationalist and positivist foundations, thus reinforcing practitioners' 'blind spots'.

\section{6. 'Mainstreaming' Peace Education Programmes}

A number of peace education programmes have been initiated, with mainstreaming as the goal, in ethnically/religiously linked post-conflict environments. Afghanistan, Angola, Burundi, Cambodia, the Democratic Republic of Congo, El Salvador, Ethiopia, Guatemala, Honduras, Lebanon, Liberia, Mozambique, Nepal, Nicaragua, Nigeria, Northern Ireland, Pakistan, Rwanda, Sierra Leone, Sri Lanka, Somalia, Sudan, and the former Yugoslavia are examples of these. ${ }^{50}$ This section reviews four of the more 'successful' examples.

\footnotetext{
46 Fountain, "Peace Education in UNICEF," 32.

47 Harris, "Peace Education Evaluation"; Salomon, "The Nature of Peace Education"; Nevo and Brem, "Peace Education Programs and the Evaluation of their Effectiveness."

48 Harris, "Peace Education Evaluation."

49 Salomon, "Peace Education," 112.

50 See e.g. Alan Smith and Alan Robinson, Education for Mutual Understanding: The Initial Statutory Years (Coleraine, Ireland: University of Ulster, 1996); Seamus Dunn and Valerie Morgan, "A Fraught Path: Education as a basis for developing improved community relations in Northern Ireland," Oxford Review of Education 25, no. 1/2 (1999): 141-53; Pamela Baxter, "The UNHCR Peace Education Programme: Skills for Life," Forced Migration Review 11 (2001): 28-30; Pamela Baxter, UNHCR Peace Education Programme (Geneva: UNHCR, 2000); Duffy, "Peace Education in a Divided Society,"; Bush and Saltarelli, The Two Faces of Education; Diane Bretherton, Jane Weston and Vic Zbar, "Peace Education in a Post-Conflict Environment: the Case of Sierra Leone," Prospects 33, no. 2 (2003): 221-30; Michael Arlow, "Citizenship Education in a Divided Society: The Case of Northern Ireland," in Education, Conflict and Social Cohesion, ed. Sabhi Tawil and Alexandra Harley (Geneva: UNESCO International Bureau of Education, 2004), 255-313; Juvenal Bazilashe Balegamire, Adelaide Dhorsan and Cristina Tembe, "Curriculum Reform, Political Change, and Reinforcement of National Identify in Mozambique," in Education, Conflict and Social Cohesion, ed. Sobhi Tawil and Alexandra Harley (Geneva: UNESCO International Bureau of Education, 2004), 207-53; Nemer Frayha, "Developing Curriculum as a Means of Bridging National Divisions in Lebanon," in Tawil and Harley, Education, Conflict and Social Cohesion, 159-205; Lal Perera, Swarna Wijetunge and Ajith S. Balasooriya, "Education Reform and Political Violence in Sri Lanka," in Tawil and Harley, Education, Conflict and Social Cohesion, 375-415; John Rutayisire, John Kabano and Jolly Rubagiza, "Redefining Rwanda's Future: The Role of Curriculum in Social Reconstruction," in Tawil and Harley, Education, Conflict and Social Cohesion, 315-73; Sommers, "Peace Education and Refugee Youth"; Stabback, "Common Curriculum, Core Curriculum or Common Curriculum Standards: Finding a Solution for Bosnia and Herzegovina"; World Bank, Reshaping the Future: Education and Post-Conflict Reconstruction (Washington DC: World Bank, 2005); Simon Harris and Nick Lewer, "Peace Education in Conflict Zones - Experience from Northern Sri Lanka," Journal of Peace Education 5, no. 2 (2008): 127-40; Mieke T.A. Lopez Cardozo, "Sri Lanka: In Peace or in Pieces? A Critical Approach to Peace Education in Sri Lanka," Research in Comparative and International Education 3, no. 1 (2008): 19-33; Lydia Allen, et al., The Peace Education Programme (PEP) Evaluation (New York, NY: Columbia School of Public Affairs, 2009);
} 


\subsection{Northern Ireland}

One of the most widely known and documented peace education initiatives has been Education for Mutual Understanding (EMU) in Northern Ireland. In 1989, the Department of Education for Northern Ireland (DENI) first introduced EMU. In 1992 it was mainstreamed and has since then been systematically embedded into the nation's educational system. The programme has sought to teach pupils

to learn to respect and value themselves and others; to appreciate the interdependence of
people within society; to know about and understand what is shared as well as what is
different about their [Protestant and Catholic] cultural traditions; and to appreciate how
conflict may be handled in non-violence ways. ${ }^{51}$

During the introductory stages of the program, a number of formative assessments looked at the progress and challenges of implementing EMU. ${ }^{52}$ However, little research has since been done to determine EMU's long-term impact on attitudinal and behavioural outcomes. ${ }^{53}$ For example, the programme has yet to receive unanimous support or adequately deal with the 'hard' issues pertaining to the divisions that persist in Irish society. ${ }^{54}$ Shifts in national priorities and financial restraints also threaten the programme's sustainability.

In a number of other post-conflict countries, diverse international actors have sought to initiate and mainstream similar peace education programmes. Actors include the United States Institute of Peace (USIP), Hague Appeal for Peace, Global Campaign for Peace Education (GCPE), International Peace Research Association (IPRA), Peace Education Centre at the Columbia University Teachers College, UN agencies (UNESCO, UNHCR, UNICEF), donor agencies, and (religious and non-religious) international non-governmental organizations (INGOs) with governmental or private funding.

Initially, International Organisations (IOs) and UN agencies such as UNESCO, UNICEF, and the UNHCR sought to mainstream peace education in post-war education systems by cooperating with ministries of education and other governmental institutions at the national level. In particular, UNICEF has sought to initiate and mainstream its peace education programmes worldwide. Some of the more notable examples include: "Global Education" in Lebanon, "Psychological Rehabilitation" in Croatia, "Peacebuilding through Schools" in Eastern and Southern Africa, "Education for Peace" in Rwanda, "Education for Conflict Resolution" in Sri Lanka, and "Values for Life" in Egypt. ${ }^{55}$ Fountain explains that "the choice of language used to describe peace education programmes in UNICEF is determined by local cultural and political sensitivities, as well as by the scope and objectives of the programme." 56 Unlike some peace education initiatives, UNICEF believes that peace education should mainstreamed and systematically integrated into an entire curriculum and education system. In an in-depth study, Fountain (1999) identifies a number of approaches UNICEF has

Smith, "The Influence of Education on Conflict and Peace Building"; Manish Thapa et al., Peace by Peace: Mainstreaming Peace Education in South Asia (Sweden: Save the Children, 2010); Fitzduff and Jean, Peace Education; UNICEF, The Role of Education in Peacebuilding: Literature Review (New York: United Nations Children's Fund, 2011); Hasan Aydin, "Education Reform in Nigeria: the Case of Multicultural Education for Peace, Love, and Tolerance," South African Journal of Education 33, no. 1 (2013): 1-19.

51 Northern Ireland Curriculum Council, Cross-curricular Themes - Guidance Materials (Belfast: NICC, 1990).

52 Smith and Robinson, Education for Mutual Understanding; Dunn and Morgan, "A Fraught Path," 141-53; Duffy, "Peace Education in a Divided Society."

${ }_{53}$ Norman Richardson, "Transformation: Diversity and Mutual Understanding in Statutory Curriculum," in Education for Diversity and Mutual Understanding: The Experience of Northern Ireland, ed. Norman Richardson and Tony Gallagher (Bern: Peterlang, 2011).

54 Duffy, "Peace Education in a Divided Society."

55 Fountain, "Peace Education in UNICEF."

56 Fountain, "Peace Education in UNICEF," 4. 
employed, such as: "curriculum development (including the production of materials for teachers and children)" as a means of "integrating peace education into traditional subjects of the existing curriculum"; "improving the school environment so that it becomes a microcosm of the more peaceful and just society"; 58 and teacher training that promotes "interactive and participatory teaching methods, organising cooperative group work, and facilitating group discussions" to "enable teachers to convey values of cooperation, respect for the opinions of children, and appreciation of differences." 59

\subsection{Sri Lanka}

In 1990, UNICEF initiated a peace education programme called "Education for Conflict Resolution" (ECR) in cooperation with the National Institute of Education in Sri Lanka. The aim has been "to create awareness and strengthen beliefs, competencies and values in nonviolent conflict resolution by creating an environment for peaceful living and co-existence." ${ }^{60}$ The programme implemented a number of curricular and pedagogical reforms, including the development of teachers' manuals to "demonstrate ways of integrating peace education into traditional subjects of existing curriculum;" ${ }^{61}$ the development of one national teacher training college as a "focal point for the development of pre-service training programmes in peace education" to ensure it was integrated into each of the traditional subjects; ${ }^{62}$ and a teacher training college that "trains school principals in conflict resolution methods before [education] students are placed in schools to do their practice teaching" to ensure "administrative support for new teachers who are attempting to introduce peace education." Whether and to what extent mainstreaming has taken root remains unknown, since ECR, like many of UNICEF's programmes, has not undergone any systematic evaluation. However, aspects of the programme, such as training and producing and integrating materials into the primary school curriculum, have reportedly produced favourable results in terms of service delivery, sustainability, capacity building, and cost effectiveness." ${ }^{\prime 4}$

These findings, however, contrast a later assessment carried out by Lopes Cardozo (2008), who pointed out a number of weaknesses and problems with ECR. She argues that educational policies to date have rarely been implemented in practice. ${ }^{65}$ In addition to UNICEF, her report draws to attention a number of other actors that have initiated a number of informal and formal peace education programmes in Sri Lanka. Some of the more notable include UNESCO, Deutsche Gesellschaft für Technische Zusammenarbeit (GIZ; German Agency for Technical Cooperation), and Christian INGO World Vision. ${ }^{66}$ Her report discusses how there has been a lack of cooperation and coherence between these organizations in developing a

\footnotetext{
57 Fountain, "Peace Education in UNICEF," 16.

58 Fountain, "Peace Education in UNICEF," 17

59 Fountain, "Peace Education in UNICEF," 19.

${ }^{60}$ Fountain, "Peace Education in UNICEF," 33.

61 Fountain, "Peace Education in UNICEF," 17.

62 Fountain, "Peace Education in UNICEF," 20.

63 Fountain, "Peace Education in UNICEF," 20

64 Fountain, "Peace Education in UNICEF," 32.

65 Cardozo, "Sri Lanka: In Peace or in Pieces?" 24.

66 World Vision (WV) is one of the most widely known faith-based INGOs. It has developed and implemented peace education projects in over 15 post-conflict countries and regions, including Burundi, Kenya, Liberia, Rwanda, Sierra Leone, Uganda, Indonesia, Philippines, Sri Lanka, Bosnian and Herzegovina, Montenegro, Kosovo, Colombia, Central America, and the Dominican Republic. See Abuigideiri Salm, "From Conflict Resolution Training to Peace Camps," in And the Children Shall Lead Them: A NGO Journey into Peace Education, ed. Bill Lowrey, Allen Harder, and Vachel Miller (Monrovia, CA: World Vision, 2005), 3-33.
} 
national plan for peace education. ${ }^{67}$ This problem has also been mentioned in a report by Save the Children. ${ }^{68}$

For the reasons mentioned above, IOs/UN agencies have started focusing on functional rather than structural approaches to mainstreaming peace education programmes. In addition to the ministries of education and governmental institutions at the national level, IOs/UN agencies have started working more at the grassroots level and in greater collaboration with a number of other international and local actors "to develop and implement context-specific, culturally appropriate, and innovative peace education curricula and in-service teacher training [programmes] in divided and [post-conflict] countries. ${ }^{969}$

\subsection{Nepal}

Greater efforts to collaborate and coordinate peace education between international and local actors can best be illustrated in the Nepal for Peace Education Project. Initially in 2006, UNICEF, UNESCO, and Save the Children Foundation partnered with the Ministry of Education and the Curriculum Development Centre to develop and pilot a four-year peace education project in Nepal. A report by Save the Children notes a number of achievements, including "mainstreaming peace, human rights and civil education in national school curricula [and] to develop training models and resource material jointly with the National Centre for Educational Development and non-formal education materials in collaboration with the Non-Formal Education Centre." ${ }^{10}$ Peace education modules designed during preservice teacher training have, since implementation, thought to have impacted an estimated 55,000 children. $^{71}$ The project's long-term impact and sustainability remains to be seen as there has been no systematic evaluation; evidence of the programmes' impact is based on preliminary assessments. However, plans are already underway to replicate the "Nepal model" in a number of other South Asian Countries, in particular Afghanistan, Pakistan, and Sri Lanka. ${ }^{72}$

\subsection{Bosnia and Herzegovina}

Since 1995, an estimated 47 out of 57 projects have been carried out by a range of international actors in Bosnia and Herzegovina (BiH), including UN-based agencies, donor agencies, and international non-governmental organizations. ${ }^{73}$ Some of the more notable international actors include Civitas, ${ }^{74}$ the Open Society Foundation, and Education for Peace. ${ }^{75}$ Each programme has offered a different approach and vision on how peace can be mainstreamed into the country's educational system, bringing with them private and governmental funding

\footnotetext{
${ }^{67}$ Cardozo, "Sri Lanka: In Peace or in Pieces?"

68 Save the Children Norway, "Building Peace Out of War."

69 Fitzduff and Jean, Peace Education, 12.

70 Thapa et al., Peace by Peace, 14.

71 Thapa et al., Peace by Peace.

72 Thapa et al., Peace by Peace.

3 Wayne Nelles, "Bosnian Education for Security and Peacebuilding?” International Peacekeeping 13, no. 2 (2006): $229-41$.

74 It should be noted that although Civitas $\mathrm{BiH}$ is a local $\mathrm{NGO}$, it was originally formed in 1996 in a joint effort by the Center for Civic Education (Calabasas, CA) and the United States Information Service (USIS), with whom it continues to maintain strong ties.

75 Marina Bowder and Valery Perry, "Returnees and the Challenges for Education Reform in Bosnia and Herzegovina in Ellison," in Education and Internally Displaced Persons, ed. Christine Smith and Alan Smith (New York: Bloomsbury, 2013); Astrid Fischer, "Integration or Segregation? Reforming the Education Sector," in Peacebuilding and Civil Society in Bosnia and Herzegovina: Ten Years After Dayton, ed. Martina Fischer, (Munster: Lit-Verlag, 2006), 297-324; Perry, "Reading, Writing, and 
to experiment with their respective peace education projects. Many programmes have offered courses and/or activities focusing on a range of issues, including democracy, human rights, peace building, and the encouragement of other post-war peaceful values. Other programmes have sought to integrate the principles of their peace education programmes into the existing curriculum and educational structures to assist in trauma recovery and developing a culture of tolerance, peace, and healing. Peace education programmes in general have represented a broader effort to assist the international community rebuild and reform BIH's entire educational system against the backdrop of a recent civil war.

Education for Peace (EFP) is of particular interest, as it has remained one of the longestrunning and largest projects of its kind. In 2000, EFP began as a poorly funded pilot project in six schools, but in a little over 12 years it has been adopted and mainstreamed as an integral part of BIH's educational system. Approximately 2200 primary and secondary schools have been reached, with about 1.5 million students and 110,000 teachers and school staff. The programme has received official recognition and endorsement from all participating school communities, the BiH Ministry of Foreign Affairs, all 13 ministers of education, and eight pedagogical institutes. Furthermore, the international community has recognized EFP including the Office of the High Representative (OHR) and the Organization for Security and Co-operation in Europe (OSCE). As of 2012, efforts have been underway to bring EFP into all eight public universities in $\mathrm{BiH}$ to train the future generation(s) of teachers, ensuring that EFP becomes a permanent feature of the entire country's educational system.

\section{Conclusion}

This article has provided a critical survey of the literature and reports on peace education - in terms of the field's history, how it has been conceptualised, how peace education as a postconflict peacebuilding tool came to exist, how it has been researched, and where mainstreaming has been tried. More importantly, it has identified two considerable short-comings - the failure to reflect on the fundamental and yet unquestioned assumptions underlying peace education programmes and the lack of any systematic evaluation with which to demonstrate their empirical worth. Finally, this article has highlighted how, apart from EMU and EFP, no other peace education programme has been systematically mainstreamed throughout an entire nation's education system.

This article has underlined the need for a serious philosophical analysis of what "peace education' is in terms of its implicit philosophical and possibly religious assumptions. Such an analysis would provide the basis for an assessment as to whether peace education has an intrinsic meaning, and, if so, whether it can be exported to other nations and contexts. In the specific case of EFP an independent, external assessment is needed to determine its effectiveness, and for this assessment an appropriate method needs to be designed.

\section{Bibliography}

Allen, Lydia, Chantal LaParl-Green, Mana Miyawaki, Nelson Monroe, Siri Siripanlch, and Brandon Thompson. The Peace Education Programme (PEP) Evaluation. New York, NY: Columbia School of Public Affairs, 2009. Ardizzone, Lisa. "Towards Global Understanding: The Transformative Role of Peace Education." Current Issues in Comparative Education 4, no. 2 (2002): 16-25.

Arlow, Michael. "Citizenship Education in a Divided Society: The Case of Northern Ireland." In, Education, Conflict and Social Cohesion, edited by Sabhi Tawil and Alexandra Harley, 255-313. Geneva: UNESCO International Bureau of Education, 2004. 
Aydin, Hasan. "Education Reform in Nigeria: the Case of Multicultural Education for Peace, Love, and Tolerance." South African Journal of Education 33, no. 1 (2013): 1-19.

Azar, Edward. The Management of Protracted Social Conflict. Aldershot: Dartmouth, 1990.

Balegamire, Juvenal Bazilashe, Adelaide Dhorsan, and Cristina Tembe. "Curriculum Reform, Political Change, and Reinforcement of National Identify in Mozambique." In Education, Conflict and Social Cohesion, edited by Sobhi Tawil and Alexandra Harley, 207-53. Geneva: UNESCO International Bureau of Education, 2004.

Bar-Tal, Daniel. "The Elusive Nature of Peace Education.” In Peace Education: The Concept, Principles, and Practices in the World, edited by Gabriel Salomon and Baruch Neve, 27-36. Mahway, NJ: Lawrence Extram, 2002.

Baxter, Pamela. UNHCR Peace Education Programme. Geneva: UNHCR, 2000.

—. "The UNHCR Peace Education Programme: Skills for Life." Forced Migration Review 11(2001): 28-30.

Beckerman, Zvi, and Claire McGlynn. Addressing Ethnic Conflict through Peace Education: International Perspectives. New York: Palgrave Macmillian, 2005.

Ben-Porath, Sigal. "War and Peace Education." Journal of Philosophy of Education 37, no. 3 (2003): 525-33.

Bowder, Marina, and Valery Perry. "Returnees and the Challenges for Education Reform in Bosnia and Herzegovina in Ellison." In Education and Internally Displaced Persons, edited by Christine Smith and Alan Smith, 142-64. New York: Bloomsbury, 2013.

Boutros-Ghali, Boutros. An Agenda for Peace. New York: United Nations, 1992.

Bretherton, Diane, Jane Weston, and Vic Zbar. "Peace Education in a Post-Conflict Environment: the Case of Sierra Leone." Prospects 33, no. 2 (2003): 221-30.

Brock-Utne, Bridget. Education for Peace: A Feminist Perspective. New York: Pergamon Press, 1985.

Bush, Kenneth D., and Saltarelli, Diana. The Two Faces of Education in Ethnic Conflict. New York: UNICEF, 2000. Cardozo, Mieke. T.A. Lopez. "Sri Lanka: In Peace or in Pieces? A Critical Approach to Peace Education in Sri Lanka." Research in Comparative and International Education 3, no. 1 (2008): 19-33.

Clarke-Habibi, Sara. "Transforming Worldviews: The Case of Education for Peace in Bosnia and Herzegovina." Journal of Transformative Education 3, no. 1 (2005): 33-56.

Danesh, H.B. "Towards an Integrative Theory of Peace Education." Journal of Peace Education 3, no. 1 (2006): 55-78.

Dobbins, James. The UN's Role in Nation-Building: From the Congo to Iraq. Santa Monica: Rand Corporation, 2005.

Dudouet, Veronique. “Transitions for Violence to Peace.” In Berghof Handbook for Conflict Transformation. Berlin: Berghof Research Center for Constructive Conflict Management, 2006.

Duffy, Terence. "Peace Education in a Divided Society: Creating a Culture of Peace in Northern Ireland." Prospects XXX, no. 1 (2000): 15-29.

Dunn, Seamus, and Valerie Morgan. "A Fraught Path: Education as a basis for developing improved community relations in Northern Ireland.” Oxford Review of Education 25, no.1/2 (1999): 141-53.

Fischer, Astrid. "Integration or Segregation? Reforming the Education Sector." In Peacebuilding and Civil Society in Bosnia and Herzegovina: Ten Years After Dayton, edited by Martina Fischer, 297-324. Munster: Lit-Verlag, 2006.

Fitzduff, Maria, and Isabella Jean. Peace Education: State of the Field and Lessons Learned From USIP Grantmaking. Washington, DC: United States Institute for Peace, 2011.

Fountain, Susan. "Peace Education in UNICEF." Working Paper Series, Programme Division, Education Section, UNICEF, New York,1999.

Frayha, Nemer. "Developing Curriculum as a Means of Bridging National Divisions in Lebanon." In Education, Conflict and Social Cohesion, edited by Sobhi Tawil and Alexandra Harley, 159-205. Geneva: UNESCO International Bureau of Education, 2004.

Galtung, Johan. Peace by Peaceful Means. London: Sage Publications Ltd., 1996.

- "Three Approaches to Peace: Peacekeeping, Peacemaking, and Peacebuilding." In Peace,War and Defense:

Essays in Peace Research Vol.2, 297-98. Copenhagen: Christian Ejlers, 1976.

Gur'Ze-ev, Ilan. Diasporic Philosophy and Counter-Education. Rotterdam: Sense Publishers, 2010a. . "Philosophy of Peace Education in a Post-Modern Era." Education Theory 51, no. 3 (2001): 315-36. 

2010b.

Harris, Ian. "The Conceptual Underpinnings of Peace Education." In Peace Education: The concept, principles and practices in the world, edited by Gabriel Salomon and Baruch Neve, 15-26. Mahwah, NJ: Lawrence Erlbaum, 2002.

. Peace Education. Jefferson, NC: McFarland, 1988.

- "Peace Education Evaluation." Paper Presented at the annual meeting of the American Educational Research Association, 21-25 April, Chicago, IL, 2003.

Harris, Simon, and Nick Lewer. "Peace Education in Conflict Zones - Experience from Northern Sri Lanka." Journal of Peace Education 5, no. 2 (2008): 127-40.

Lederach, John P. Building Peace: Sustainable Reconciliation in Divided Societies. Washington, DC: United States Institute for Peace, 1997.

Nelles, Wayne. "Bosnian Education for Security and Peacebuilding?" International Peacekeeping 13, no. 2 (2006): 229-41.

Neve, Baruch, and Iris Brem. "Peace Education Programs and the Evaluation of their Effectiveness." In Peace education: The concept, principles and practices in the world, edited by Gabriel Salomon and Baruch Neve, 271-82. Mahwah, NJ: Lawrence Erlbaum, 2002.

Northern Ireland Curriculum Council. Cross-curricular Themes - Guidance Materials. Belfast: NICC, 1990.

Paris, Roland. "International Peacebuilding and "Mission Civilistrace." Review of International Studies 28, no. 4 (2002): 637-56.

Perera, Lal, Swarna Wijetunge, and Ajith S. Balasooriya. "Education Reform and Political Violence in Sri Lanka." In Education, Conflict and Social Cohesion, edited by Sohbi Tawil and Alexandra Harley, 375-415. Geneva: UNESCO International Bureau of Education, 2004.

Perry, Valerie. "Reading, Writing, and Reconciliation: Educational Reform in Bosnia and Herzegovina." Working Paper no. 18, European Centre for Minority Issues, Flensburg, 2003.

Perry, Valerie, and Soeren Keil. "The OSCE Mission in Bosnia and Herzegovina: Testing the Limits of Ownership." Nationalities Papers: The Journal of Nationalism and Ethnicity 41, no. 3 (2013): 71-394.

Pavone, Vincenzo. From the Labyrinth of the World to the Paradise of the Heart: Science and Humanism in UNESCO's Approach to Globalization. Plymouth, UK: Lexington Books, 2008.

Pigozzi, Mary. Education in Emergencies and for Reconstruction: A Developmental Approach. New York: United Nations Children's Fund, 1999.

Reardon, Betty. Comprehensive Peace Education: Educating for Global Responsibility. New York: Teachers College Press, 1988.

Richardson, Norman. “Transformation: Diversity and Mutual Understanding in Statutory Curriculum.” In Education for Diversity and Mutual Understanding: The Experience of Northern Ireland, edited by Norman Richardson and Tony Gallagher. Bern: Peterlang, 2011.

Rutayisire, John, John Kabano, and Jolly Rubagiza. "Redefining Rwanda's Future: The Role of Curriculum in Social Reconstruction." In Education, Conflict and Social Cohesion, edited by Sobhi Tawil and Alexandra Harley, 315 73. Geneva: UNESCO International Bureau of Education, 2004.

Salazar Tetzagüic, Manuel de Jesús, and Katherine Grigsby. "Curriculum Change and Social Cohesion in Multicultural Guatemala." In Education, Conflict and Social Cohesion, edited by Sobhi Tawil and Alexandra Harley, 85-157. Geneva: UNESCO International Bureau of Education, 2004.

Salm, Abuigideiri. "From Conflict Resolution Training to Peace Camps." In And the Children Shall Lead Them: A NGO Journey into Peace Education, edited by Bill Lowrey, Allen Harder, and Vachel Miller, 3-33. Monrovia, CA: World Vision, 2005.

Salomon, Gabriel. "The Nature of Peace Education: Not All Programs Are Created Equal." In Peace Education: The concept, principles and practices in the world, edited by Gabriel Salomon and Baruch Neve, 3-14. Mahwah, NJ: Lawrence Erlbaum, 2002.

—. "Peace Education: Its Nature, Nurture, and the Challenges it Faces." In Handbook on Building Cultures of Peace, edited by Joseph de Rivera, 107-21. New York: Springer Science+Business Media, LLC, 2009. 
Salomon, Gabriel, and Baruch Neve. Peace Education: The Concept, Principles, and Practices around the World. New York: Psychology Press, 2002.

Save the Children Alliance. Where Peace Begins: Education's Role in Conflict Prevention and Peacebuilding. London: International Save the Children Alliance, 2008.

Save the Children Norway. "Building Peace Out of War: Children and Young People as Agents of Peace- The Young Generations Challenge.” Paper presented at the International Conference, Oslo Norway, June 29-July 3, 2005.

Seitz, Klaus. Education and Conflict: The Role of Education in the Creation, Prevention, and Resolution of Societal Crises - Consequences for Development Cooperation. Postfach: German Technical Cooperation, 2004.

Smith, Alan. "The Influence of Education on Conflict and Peace Building." Paper prepared for the Education for All Global Monitoring Report 2011-The Hidden Crisis: Armed Conflict and Education, UNESCO, Paris: 2010.

Smith, Alan, and Alan Robinson. Education for Mutual Understanding: The Initial Statutory Years. Coleraine, Ireland: University of Ulster, 1996.

Smith, Alan, and Tony Vauz. Education, Conflict, and International Development. London: Department of International Development, 2002.

Smith, Dan. "Trends and Causes of Armed Conflict." In Berghof Handbook for Conflict Tranformation. Berlin: Berghof Research Center for Constructive Conflict Management, 2000.

Sommers, Marc. "Peace Education and Refugee Youth.” In Learning for a Future: Refugee Education in Developing Countries, edited by Jeff Crisp, Christopher Talbot and Daiana B. Cipollone, 163-216. Geneva: UNHCR, 2002.

Stabback, Philip. "Common Curriculum, Core Curriculum or Common Curriculum Standards: Finding a Solution for Bosnia and Herzegovina." Prospects 37, no. 4 (2007): 449-67.

. "Curriculum Development, Diversity and Division in Bosnia and Herzegovain." In Education, Conflict and Social Cohesion, edited by Sobhi Tawil and Alexandra Harley, 37-84. Geneva: UNESCO International Bureau of Education, 2007.

Steinburg, Gerald. "The Thin Line Between Peace Education and Political Advocacy: Toward a Code of Conduct." In Educating Towards a Culture of Peace, edited by Yaacov Iram, 13-22. Greenwhich, CT: Information Age, 2004.

Tawil, Sobhi, and Alexandra Harley. Education, Conflict and Social Cohesion. Geneva: UNESCO International Bureau of Education, 2004.

Tent, James. Mission on the Rhine: Reeducation and Denazification in American-Occupied Germany. Chicago: University of Chicago, 1982.

Thapa, Manish, Raj Kumar Dhungana, Bhuvaneswari Mahalingam, and Jerome Conilleau. Peace by Peace: Mainstreaming Peace Education in South Asia. Sweden: Save the Children, 2010. http://resourcecentre. savethechildren.se/sites/default/files/documents/3255.pdf

Tomlinson, Kathryn, and Pauline Benefield. Education and Conflict: Research and Research Possibilities. Berkshire, UK: National Foundation for Educational Research, 2005.

UNESCO. Constitution of the United Nations Educational, Scientific and Cultural Organization. London: UNESCO, 1945.

UNICEF. The Role of Education in Peacebuilding: Literature Review. New York: United Nations Children's Fund, 2011.

World Bank. Reshaping the Future: Education and Post-Conflict Reconstruction. Washington DC: World Bank, 2005. 